\title{
PENERAPAN MODEL PROBLEM BASED LEARNING DALAM MENINGKATKAN KEMAMPUAN BERPIKIR ANALITIS DAN KETERAMPILAN PROSES SAINS PESERTA DIDIK SMA
}

\author{
Klaudius Ware ${ }^{1}$ dan Eli Rohaeti \\ ${ }^{1}$ Program Studi Pendidikan Kimia, Program Pascasarjana, \\ Universitas Negeri Yogyakarta \\ *E-mail: klaudiuskayucary@gmail.com
}

\begin{abstract}
ABSTRAK
Tujuan penelitian yaitu menguji pengaruh penerapan model problem based learning terhadap kemampuan berpikir analitis dan keterampilan proses sains peserta didik SMA Negeri 1 Sleman pada materi larutan penyangga. Sampel dalam penelitian ini yaitu, 63 peserta didik SMA Negeri 1 Sleman terbagi atas kelas eksperimen yang mengikuti pembelajaran dengan model problem based learning dan kelas kontrol yang mengikuti pembelajaran dengan model 5M (Mengamati, Menanya, Mengumpulkan Data, Mengasosiasi, dan Mengkomunikasikan). Kemampuan berpikir analitis dan keterampilan proses sains diukur dengan integrated assessment. Hasil penelitian menunjukkan bahwa nilai sig $<0,05$ yaitu $0,000<0,05$, dengan demikian terdapat pengaruh penerapan model problem based learning terhadap kemampuan berpikir analitis dan keterampilan proses sains peserta didik SMA Negeri 1 Sleman pada materi larutan penyangga.
\end{abstract}

Kata kunci: kemampuan berpikir analitis, keterampilan proses sains, larutan penyangga, problem based learning.

\begin{abstract}
The purpose of this study was to inivestigate the effect of problem based learning model on analytical thinking skills and science process skills of the students of class XI SMA Negeri 1 Sleman on the subject of buffer solution. The sample were 63 students in students SMA Negeri 1 Sleman, that is experimental class which followed problem based learning model and control class which followed $5 \mathrm{M}$ model. The analytical thinking skills and science process skills were measured by integrated assessment. The result of this research shows that sig $<0.05$ that $0.00<0.05$, thus there is effect of problem based learning model on analytical thinking skills and science process skills of the students of class XI SMA Negeri 1 Sleman on the subject of buffer solution.
\end{abstract}

Keyword: analytical thinking skills, science process skills, buffer solution, problem based learning.

DOI: https://doi.org/10.15575/jtk.v3i1.2219 


\section{PENDAHULUAN}

Pembelajaran pada hakekatnya merupakan upaya mengkondisikan seseorang agar bisa belajar dengan baik sesuai dengan tujuan pembelajaran. Proses pembelajaran merupakan tindakan penyampaian ilmu pengetahuan dan perubahan tingkah laku. Pembelajaran tidak hanya kegiatan yang dilakukan oleh guru, tetapi mencakup kegiatan yang terjadi selama proses belajar peserta didik (Majid, 2013).

Pembelajaran yang berkualitas merupakan pembelajaran yang mengandung nilai yang berkaitan dengan tujuan, proses dan pencapaian kriteria sesuai standar, serta dilakukan dengan efektif dan efisien. Pembelajaran yang efektif dilaksanakan melalui proses yang interaktif dan menyenangkan. Peserta didik diharapkan secara efektif, mampu mengembangkan dirinya menggunakan sumber belajar (Sujarwo, 2014).

Pembelajaran yang berkualitas dilihat dari model, pendekatan atau strategi yang digunakan. Proses pembelajaran diharapkan ada kreativitas dan motivasi, agar peserta didik dapat lebih mudah memahami materi yang disampaikan dalam pembelajaran kimia.

Kemampuan memecahkan masalah kimia peserta didik masih rendah, sehingga perlu ditingkatkan. Kondisi tersebut sesuai dengan pendapat Supiandi \& Julung (2016) bahwa kemampuan memecahkan masalah peserta didik belum optimal. Pada saat proses pembelajaran, guru belum memunculkan fenomena-fenomena yang terjadi berkaitan dengan materi untuk dicari solusinya. Proses pembelajaran demikian belum mengarahkan peserta didik pada sebuah permasalahan. Cara yang dapat dilakukan dalam meningkatkan kemampuan memecahkan masalah yaitu dengan melatih dan memberikan penilaian pada aspek kognitif, afektif, dan psikomotorik peserta didik. Ketiga kompetensi ini saling berkaitan, oleh karena itu dalam pembelajaran ketiganya akan muncul secara bersamaan. Kompetensi kognitif terwujud berupa penerapan materi, kompetensi afektif terbentuk lewat pemenuhan rasa ingin tahu, latihan, kerjasama, komunikasi dan menghargai ilmu, serta kompetensi psikomotorik dilatih melalui keterampilan menggunakan alat dan bahan serta mendemonstrasikan suatu fenomena (Pertiwi \& Husna, 2013).

Rezba et al. (2007) menyatakan bahwa keterampilan proses sains terdiri atas keterampilan proses dasar dan keterampilan proses terintegrasi. Keterampilan proses dasar meliputi melaksanakan, mengobservasi, memprediksi, menginferensi, mengkomunikasikan, dan mengukur. Keterampilan terintegrasi meliputi mengidentifikasikan variabel, merumuskan hipotesis, investigasi, mentabulasi dan membuat grafik, mendefinisikan variabel, merancang investigasi dan bereksperimen. Pada umumnya, penilaian keterampilan proses sains di sekolah masih jarang dilakukan. Fenomena ini didukung oleh Siwa dkk. (2013) yang mengungkapkan bahwa pembelajaran lebih banyak menekankan pada dimensi kognitif yang rendah sedangkan proses kognitif yang lebih tinggi jarang disentuh.

Montaku et al.,(2012) menyatakan bahwa berpikir analitis merupakan berpikir untuk mengelompokan menjadi beberapa bagian berdasarkan alasan, tingkat korelasi, pembacaan diagram, sebuah perbedaan, fokus, prinsip, fungsi yang berkaitan dengan kondisi kehidupan. Sun \& Hui (2012) berpendapat bahwa indikator dari kemampuan berpikir analitis, yaitu kemampuan membedakan (differentiating), mengorganisasikan (organizing), dan menghubungkan (attributing).

Selain penilaian keterampilan proses sains, adapun penilaian terhadap kemampuan berpikir analitis. Berpikir pada tingkat yang lebih tinggi bukan hanya sekedar menghafalkan fakta, melainkan usaha mengeksplorasi pengalaman yang kompleks, reflektif, dan kreatif yang dilakukan secara sadar untuk mencapai tujuan, yaitu memperoleh pengetahuan meliputi tingkat 


\section{K. Ware \& E. Rohaeti}

berpikir analitis, sintesis dan evaluatif (Rofiah dkk., 2013).

Pada kenyataannya, masih banyak peserta didik yang kesulitan dalam memahami konsep kimia (Priadi dkk., 2012; Sugiarti \& Bija, 2012). Penerapan konsep kimia tersebut dapat ditemukan di lingkungan sekitar dan bahkan dalam setiap aspek kehidupan. Adanya kecenderungan siswa menghafal konsepkonsep kimia tanpa menghubungkan dengan penerapan konsep, diduga menjadi penyebab terjadinya kesulitan siswa memecahkan masalah kimia (Sugiarti \& Bija, 2012). Hal tersebut juga mengakibatkan siswa menganggap kimia sebagai pelajaran yang sulit (Rahmawanna et al., 2016). Oleh karena itu, suatu konsep kimia membutuhkan pemahaman bukan hanya penghafalan (Sugiarti \& Bija, 2012).

Berdasarkan hasil wawancara terhadap guru kimia di SMA Negeri 1 Sleman, diketahui bahwa peserta didik jarang diberikan kesempatan untuk menemukan dan memecahkan masalah, sehingga kemampuan memecahkan masalah peserta didik tidak dapat berkembang secara optimal. Pernyataan tersebut mengandung makna
Penerapan Model Problem Based Learning dalam Meningkatkan Kemampuan Berpikir Analitis dan Keterampilan Proses Sains Peserta Didik SMA

bahwa model problem based learning belum diterapkan dalam pembelajaran kimia, khususnya pada materi larutan penyangga, sehingga kemampuan berpikir analitis dan keterampilan proses sains belum optimal.

Dengan demikian penerapan model problem based learning untuk meningkatkan kemampuan berpikir analitis dan keterampilan proses sains peserta didik kelas XI SMA Negeri 1 Sleman pada materi larutan penyangga sangat perlu dilakukan.

\section{METODE PENELITIAN}

Penelitian ini dilaksanakan di SMA Negeri 1 Sleman, Kabupaten Sleman, Daerah Istimewa Yogyakarta. Populasi dalam penelitian ini yaitu seluruh peserta didik kelas XI SMA Negeri 1 Sleman Tahun Ajaran 2016/2017 yang berjumlah 135 peserta didik. Sampel dalam penelitian ini yaitu peserta didik kelas XI SMA Negeri 1 Sleman yang terdiri atas dua kelas, yaitu kelas eksperimen dan kelas kontrol dengan jumlah sampel sebanyak 63 peserta didik. Alur teknik pengumpulaan data dalam penelitian ini disajikan dalam Gambar 1.

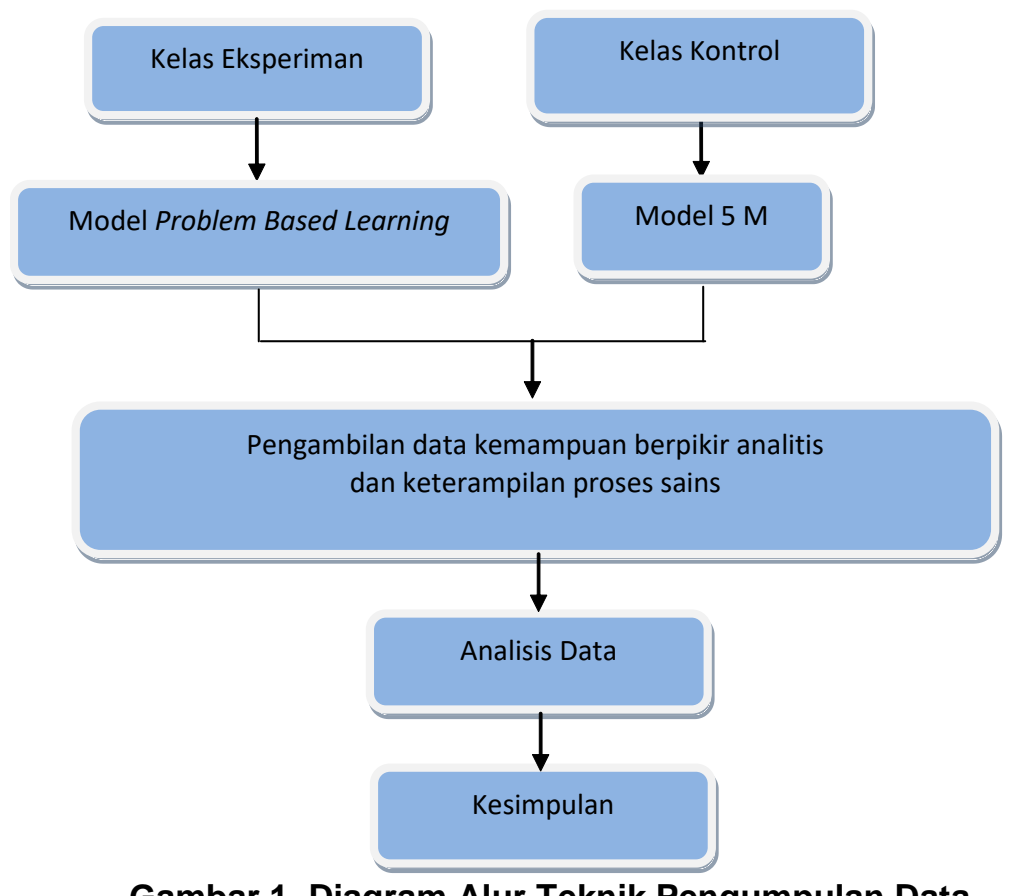

Gambar 1. Diagram Alur Teknik Pengumpulan Data 


\section{K. Ware \& E. Rohaeti}

Penelitian ini terdiri atas dua variabel yaitu, variabel bebas dan variabel terikat. Variabel bebas dalam penelitian ini, yaitu model problem based learning, sedangkan variabel terikat terdiri atas kemampuan berpikir analitis dan keterampilan proses sains peserta didik.

Indikator kemampuan berpikir analitis yaitu, membedakan, menghubungkan, dan mengorganisasikan. Keterampilan proses sains terdiri atas indikator melaksanakan percobaan, memprediksi, mengklasifikasi, menginterpretasi, menerapkan konsep, dan mengkomunikasi.

Analisis data yang digunakan dalam penelitian ini, yaitu analisis univariat satu faktor (one-way anova). One-way anova bertujuan untuk menguji ada atau tidaknya pengaruh model problem based learning terhadap kemampuan berpikir analitis dan keterampilan proses sains.

\section{Penerapan Model Problem Based Learning dalam Meningkatkan Kemampuan Berpikir Analitis dan Keterampilan Proses Sains Peserta Didik SMA}

Pembelajaran dengan model problem based learning terdiri atas 5 tahapan, yaitu

1) Orientasi masalah: pada tahap ini, guru harus menyampaikan tujuan pembelajaran, permasalahan yang akan dibahas aktivitas apa yang dilakukan, dan bagaimana cara guru mengevaluasi pembelajaran. Dalam pemecahan masalah, guru harus bisa memberikan motivasi pada siswa agar dapat terlibat secara aktif.

2) Pengorganisasian belajar; guru membantu siswa mengorganisir pembelajaran seperti membuat kelompok kecil, mengarahkan membaca masalah dan membuat hipotesis.

3) Melakukan penyelidikan mandiri dan kelompok; pada tahap ini siswa mengumpulkan informasi sebanyakbanyaknya, misalnya melalui eksperimen maupun ide mereka sendiri untuk dapat menyelesaikan masalah.

Tabel 1. Kisi-kisi Keterampilan Proses Sains

\begin{tabular}{|c|c|c|}
\hline No. & Indikator & Aspek yang diukur \\
\hline \multirow[t]{7}{*}{1.} & \multirow[t]{7}{*}{ Melaksanakan percobaan } & Mengamati larutan \\
\hline & & Mengamati perubahan $\mathrm{pH}$ larutan \\
\hline & & Mengukur bahan kimia \\
\hline & & Menggunakan gelas ukur \\
\hline & & Menggunakan pipet tetes \\
\hline & & Menggunakan indikator universal \\
\hline & & Menuangkan larutan ke dalam gelas ukur \\
\hline 2. & Memprediksi & Memprediksi larutan berdasarkan $\mathrm{pH}$ \\
\hline 3. & Mengklasifikasi & Mengklasifikasikan larutan berdasarkan pH \\
\hline \multirow[t]{2}{*}{4.} & \multirow[t]{2}{*}{ Menginterpretasi } & Menuliskan reaksi kimia \\
\hline & & Menuliskan fase reaksi \\
\hline 5. & Menerapkan konsep & Menghitung $\mathrm{pH}$ larutan \\
\hline \multirow[t]{4}{*}{6.} & \multirow[t]{4}{*}{ Mengkomunikasi } & Menyajikan data percobaan \\
\hline & & Melaporkan data \\
\hline & & Menjelaskan konsep larutan penyangga \\
\hline & & Menjelaskan fungsi larutan penyangga \\
\hline
\end{tabular}


Tabel 2. Kisi-kisi Instrumen Tes Integrated Assessment

\begin{tabular}{|c|c|c|c|c|}
\hline No. & Indikator pembelajaran & $\begin{array}{c}\text { Indikator } \\
\text { science process skills }\end{array}$ & $\begin{array}{c}\text { Indikator } \\
\text { analytical thinking skills }\end{array}$ & $\begin{array}{l}\text { No } \\
\text { Soal }\end{array}$ \\
\hline \multirow[t]{9}{*}{1.} & \multirow{9}{*}{$\begin{array}{l}\text { Menganalisis larutan } \\
\text { penyangga dan bukan } \\
\text { penyangga melalui percobaan }\end{array}$} & Memprediksi & Membedakan & 1.a. \\
\hline & & Mengkomunikasi & Menghubungkan & 1.b. \\
\hline & & $\begin{array}{l}\text { Merencanakan } \\
\text { percobaan }\end{array}$ & Menghubungkan & 2.a. \\
\hline & & Menerapkan konsep & Mengorganisasikan & 2.b. \\
\hline & & Mengkomunikasikan & Mengorganisasikan & 2.c. \\
\hline & & Menginterpretasi & Membedakan & 3 \\
\hline & & $\begin{array}{l}\text { Merencanakan } \\
\text { percobaan }\end{array}$ & Mengorganisasikan & 4.a. \\
\hline & & Menerapkan konsep & Menghubungkan & 4.b. \\
\hline & & Memprediksi & Membedakan & 4.c. \\
\hline \multirow[t]{10}{*}{2.} & \multirow{10}{*}{$\begin{array}{l}\text { Menghitung } \mathrm{pH} \text { atau } \mathrm{pOH} \\
\text { larutan penyangga }\end{array}$} & Menerapkan konsep & Mengorganisasikan & 5.a. \\
\hline & & Mengklasifikasi & Menghubungkan & 5.b. \\
\hline & & Mengkomunikasi & Menghubungkan & 5.c. \\
\hline & & Menerapkan konsep & Mengorganisasikan & 7.a. \\
\hline & & Mengklasifikasi & Menghubungkan & 7.b. \\
\hline & & Menerapkan konsep & Mengorganisasikan & 8.a. \\
\hline & & Mengklasifikasi & Menghubungkan & 8.b. \\
\hline & & Menerapkan konsep & Mengorganisasikan & 9.a. \\
\hline & & Mengklasifikasi & Menghubungkan & 9.b. \\
\hline & & Mengkomunikasikan & Menghubungkan & 9.c. \\
\hline \multirow[t]{6}{*}{3.} & \multirow{6}{*}{$\begin{array}{l}\text { Menghitung pH larutan } \\
\text { penyangga dengan } \\
\text { penambahan sedikit asam } \\
\text { atau sedikit basa atau dengan } \\
\text { pengenceran }\end{array}$} & Menerapkan konsep & Mengorganisasikan & 6.a. \\
\hline & & Menerapkan konsep & Mengorganisasikan & 6.b. \\
\hline & & Menerapkan konsep & Mengorganisasikan & 6.c. \\
\hline & & Mengklasifikasi & Menghubungkan & 6.d. \\
\hline & & Menerapkan konsep & Mengorganisasikan & 10.a. \\
\hline & & Mengkomunikasikan & Menghubungkan & 10.b. \\
\hline \multirow[t]{5}{*}{4.} & \multirow{5}{*}{$\begin{array}{l}\text { Menjelaskan fungsi larutan } \\
\text { penyangga dalam tubuh } \\
\text { makhluk hidup }\end{array}$} & Mengkomunikasikan & Membedakan & 11.a. \\
\hline & & Menginterpretasi & Mengorganisasikan & 11.b. \\
\hline & & Mengkomunikasikan & Mengorganisasikan & 12.a. \\
\hline & & Mengkomunikasikan & Menghubungkan & 12.b. \\
\hline & & Memprediksi & Menghubungkan & 12.c. \\
\hline
\end{tabular}

4) Mengembangkan dan mempresentasikan hasil karya; data/ informasi yang didapatkan diolah dan dianalisis sesuai dengan masalah yang telah dirumuskan, sehingga siswa mampu memberikan argumen untuk penyelesaian masalah yang dapat disajikan dalam bentuk laporan, video, model, presentasi, dan lain-lain.

5) Menganalisis dan mengevaluasi proses pemecahan masalah; guru meminta siswa merekonstruksi pemikiran dan aktivitas yang telah dilakukan untuk dievaluasi bersama. (Arends, 2012:411; Ningsih, 2015).

\section{HASIL DAN PEMBAHASAN}

Sebelum dilakukan uji hipotesis penelitian, terlebih dahulu dilakukan uji korelasi antar variabel kemampuan berpikir analitis dan keterampilan proses sains dengan pengetahuan awal peserta didik, serta uji normalitas dan uji homogenitas. Analisis hipotesis dilakukan degan statistik uji univariat menggunakan program SPSS 22.

Hasil analisis menunjukan bahwa nilai signifikansi output, yaitu 0,000 lebih kecil dari taraf signifikan 0,05. Dengan demikian, dapat 
disimpulkan bahwa pada taraf signifikan 0,05, ada pengaruh model problem based learning

terhadap kemampuan berpikir analitis dan keterampilan proses sains peserta didik SMA
Negeri 1 Sleman pada materi larutan penyangga. Hasil uji prasyarat dan uji hipotesis dapat dilihat pada Tabel 3 dan Tabel 4

Tabel 3. Hasil Uji Prasyarat

\begin{tabular}{|c|l|c|c|c|}
\hline \multirow{2}{*}{ No. } & \multirow{2}{*}{$\begin{array}{c}\text { Uji } \\
\text { Prasyarat }\end{array}$} & \multicolumn{2}{|c|}{ Variabel } & \multicolumn{2}{|c|}{ Nilai Signifikansi } \\
\cline { 4 - 6 } & Korelasi & $\begin{array}{c}\text { Pengetahuan awal dan } \\
\text { Integrated assessment }\end{array}$ & \multicolumn{2}{|c|}{0,325} \\
\hline 2. & Normal & Integrated assessment & 0,200 & 0,200 \\
\hline 3. & Homogen & Integrated assessment & \multicolumn{2}{|c|}{0,114} \\
\hline
\end{tabular}

Tabel 4. Hasil Uji Hipotesis

\begin{tabular}{|c|c|c|}
\hline No. & Statistik Uji & Signifikansi \\
\hline 1. & Anava & 0,000 \\
\hline
\end{tabular}

Pengaruh penerapan model problem based learning terhadap kemampuan berpikir analitis dan keterampilan proses sains peserta didik dapat dilihat dari hasil uji Anava memberikan hasil bahwa ada pengaruh model problem based learning terhadap kemampuan berpikir analitis dan keterampilan proses sains peserta didik. Hasil uji Anava menunjukan nilai signifikansi lebih kecil dari nilai $\alpha$, sehingga dapat disimpulkan bahwa pada taraf signifikansi $5 \%$, penerapan model problem based learning dapat berpengaruh terhadap peningkatan kemampuan berpikir analitis dan keterampilan proses sains peserta didik kelas XI SMA Negeri 1 Sleman pada materi larutan penyangga.

Hasil uji hipotesis ini didukung oleh penelitian Wahyudi dkk. (2015) yang menyatakan bahwa problem based learning berpengaruh terhadap rata-rata nilai keterampilan proses sains peserta didik. Problem based learning sangat baik untuk meningkatkan keterampilan proses sains peserta didik, karena pembelajaran konvensional kurang mengakomodasi keterampilan proses sains. Perbedaan nilai antara kelas eksperimen dan kelas kontrol disebabkan karena pada kelas eksperimen, peserta didik lebih antusias mengikuti kegiatan pembelajaran. Pada kelas eksperimen peserta didik lebih serius mengerjakan tugas-tugas yang diberikan dan puncaknya saat presentasi di depan kelas peserta didik lebih antusias dan kondusif. Hasil penelitian serupa juga dikemukakan oleh Novita dkk. (2014) bahwa terdapat perbedaan yang signifikan pada keterampilan proses sains antara kelompok peserta didik yang mengikuti pembelajaran dengan model pembelajaran problem based learning dan kelompok peserta didik yang mengikuti pembelajaran dengan model pembelajaran konvensional. Adanya perbedaan yang signifikan menunjukkan bahwa pembelajaran menggunakan model pembelajaran problem based learning memberikan pengaruh terhadap keterampilan proses sains peserta didik.

Temuan tersebut juga serupa dengan penelitian yang dilakukan oleh Pramudita dkk. (2014) berdasarkan analisis data mengenai skor capaian kemampuan berpikir analitis peserta didik, dapat diketahui bahwa model pembelajaran $P B L$ memberikan pengaruh positif terhadap kemampuan berpikir analitis 
peserta didik. Hasil penelitian serupa juga dikemukakan oleh Dawati dkk. (2015) bahwa kemampuan berpikir analitis peserta didik pada kelas eksperimen yang menerapkan model PBL disertai Mind Map lebih baik daripada kelas kontrol yang menerapkan metode konvensional dengan ceramah. Berdasarkan uraian hasil penelitian tersebut menunjukkan bahwa model $P B L$ disertai Mind Map dapat meningkatkan kemampuan berpikir analitis peserta didik. Dengan demikian, model $P B L$ disertai Mind Map efektif untuk pencapaian kemampuan berpikir analitis peserta didik.

Abdurrozak dkk. (2016) mengungkapkan bahwa pembelajaran IPA dengan menggunakan model $P B L$ terbukti dapat meningkatkan hasil belajar peserta didik. Hal tersebut dilihat dari hasil perhitungan uji statistik yang diperoleh. Pembelajaran dengan menggunakan model $P B L$ lebih baik dalam meningkatkan kemampuan berpikir kreatif peserta didik dibandingkan dengan menggunakan model konvensional. Hasil tersebut diperoleh dari analisis data pre-test post-test kelas eksperimen dan kontrol. Hal ini menunjukkan bahwa model $P B L$ lebih baik dalam meningkatkan kemampuan berpikir kreatif peserta didik dibandingkan dengan menggunakan model konvensional.

Hasil penelitian serupa juga dilakukan oleh Utrifani \& Turnip (2014) menjelaskan bahwa nilai rata-rata post-test kelas eksperimen lebih tinggi dibandingkan dengan nilai ratarata post-test kelas kontrol sehingga dapat dikatakan bahwa ada pengaruh model pembelajaran problem based learning terhadap hasil belajar. Observasi didapatkan bahwa model pembelajaran problem based learning dapat meningkatkan aktivitas belajar peserta didik. Hasil penelitian Hinderasti dkk. (2013) menyatakan bahwa ada perbedaan hasil belajar antara peserta didik yang mengikuti pembelajaran biologi menggunakan model $P B L$ dengan metode eksperimen disertai teknik Roundhouse Diagram dan Mind Map, baik aspek kognitif, afektif, maupun psikomotorik. Penelitian yang lain dilakukan oleh Idowu et al. (2016) menyatakan bahwa peserta didik mendapatkan pemahaman yang lebih baik pada proses problem based learning. Peserta didik juga menemukan pengalaman bermanfaat karena dengan model problem based learning dapat membantu peserta didik bekerja dalam tim dan presentasi keterampilan yang baik, mampu memberi dan menerima kritikan dari temannya.

Hasil penelitian serupa juga dijelaskan oleh Mühlfelder et al. (2015) bahwa keterampilan metakognisi dari $P B L$ berkorelasi secara positif dengan tingkat kepuasan peserta didik terhadap hasil belajar. Hasil penelitian yang dilakukan oleh Alrahlah (2016) menunjukkan bahwa melalui $P B L$, peserta didik belajar berkelompok dalam proses belajar mengajar; respon terhadap apa yang mereka pelajari, berhasil bekerja dalam sebuah tim dalam mengatasi perubahan situasi. Oleh karena itu, $P B L$ dapat meningkatkan kemampuan berpikir kritis peserta didik, mengajarkan peserta didik menganalisis dan memecahkan masalah nyata, mempersiapkan peserta didik dalam dunia kerja.

Hasil penelitian serupa juga dijelaskan oleh Schmidt et al. (2011) bahwa PBL berpengaruh cukup kuat pada pembelajaran dan prestasi dibandingkan dengan kondisi dimana pembelajaran tidak menggunakan masalah. Penelitian ini secara umum menunjukkan bahwa hasil belajar peserta didik dengan $P B L$ lebih tinggi daripada kelas kontrol.

Hasil penelitian yang dilakukan oleh Desriyanti \& Lazulva (2016) menunjukkan bahwa terdapat perbedaan yang signifikan antara nilai post-test pada kelas eksperimen yang diperlakukan dengan problem based learning dan post-test pada kelas kontrol dengan rata-rata nilai post-test dari kelas eksperimen adalah 83,75 sedangkan rata-rata nilai post-test kelas kontrol adalah 79,545. Selain itu penelitian yang dilakukan oleh (Ansarian et al., 2016; Jufrina \& Utami, 2016; Üce \& Ateş, 2016) juga menunjukan bahwa terdapat perbedaan yang signifikan antara 
pre-test dan post-test peserta didik pada kelas eksperimen yang diperlakukan dengan problem based learning. Hasil tersebut membuktikan bahwa problem based learning berpengaruh signifikan secara positif.

\section{KESIMPULAN}

Berdasarkan hasil penelitian dan pembahasan dapat disimpulkan bahwa penerapan model problem based learning berpengaruh dalam meningkatkan kemampuan berpikir analitis dan keterampilan proses sains peserta didik SMA Negeri 1 Sleman pada materi larutan penyangga. 


\section{DAFTAR PUSTAKA}

Abdurrozak R., Jayadinata, A.K., \& Atun, I. (2016). Pengaruh Model Problem Based Learning terhadap Kemampuan Berpikir Kreatif Siswa. Jurnal Pena IImiah, 1(1), 871-880.

Alrahlah, A. (2016). How Effective the Problem-Based Learning (PBL) in Dental Education. A Critical Review. The Saudi Dental Journal, 28, 155-161.

Ansarian, L., Adlipour, A.A., Saber, M.A., et.al. (2016). The Impact of Problem-Based Learning on Iranian EFL Learners' Speaking Proficiency. Australian International Academic Centre, Australia, 7(3), 84-94.

Arends, R.I. (2012). Learning to Teach. United State of America: McGraw Hill Companies.

Dawati, H.N.M., Karyanto, P., \& Sugiharto, B. (2015). Perbedaan Kemampuan Berpikir Analitis pada Model Problem Based Learning disertai Mind Map dengan Kelas Konvensional pada Siswa Kelas X IPA SMA Al Islam 1 Surakarta Tahun Pelajaran 2013/ 2014. Jurnal Pendidikan Biologi, 7(2), 102-113.

Desriyanti,R., \& Lazulva. (2016). Penerapan Problem Based Learning pada Pembelajaran Hidrolisis Garam Untuk Meningkatkan Hasil Belajar Siswa. Jurnal Tadris Kimiya, 1,(2), 77.

Hinderasti, N.E.K., Suciati, \& Prayitno, B.A. (2013). Pengaruh Model Problem Based Learning dengan Metode Eksperimen Disertai Teknik Roundhouse Diagram dan Mind Map terhadap Hasil Belajar Biologi ditinjau dari Gaya Belajar dan Motivasi Belajar Siswa. Bioedukasi, 6(2) 10-27.

Idowu, Y., Muir, E. \& Easton, G. (2016). Problem-based Learning Case Writing by Students Based on Early Years Clinical Attachments: a Focus Group
Evaluation. Journal of the Royal Society of Medicine Open, $\mathrm{O}(0), 1-8$.

Jufrina, Y., \& Utami, L. (2016). Pembelajaran Berbasis Masalah untuk Meningkatkan Keterampilan Berpikir Kritis Siswa pada Materi Reaksi Redoks. Jurnal Tadris Kimiya, 1(2), 58-63.

Majid, A. (2013). Strategi Pembelajaran. Bandung: PT Remaja Rosdakarya.

Montaku, S., Kaittikomol, P., \& Tiranathanakul, P. (2012). The Model Of Analitytical Thinking Skill Training Process. Research Journal of Applied Sciences, 7(1), 17-20.

Mühlfelder, M., Konermann, T., \& Borchard, L.M. (2015). Design, Implementation, and Evaluation of a Tutor Training for Problem Based Learning in Undergraduate Psychology Courses. Journal of Problem, 3(2). 37-61.

Ningsih, S. (2015). Model Pembelajaran Based Learning dalam Kurikulum 2013. (https://www.kompasiana.com/suryanin gsihwardana/model-pembelajaranproblem-based-learning-dalamkurikulum2013_54f683a3a33311e6048b4f14), diakses, 29 Juni 2018.

Novita, G.A.D.L., Sudana, D.N., \& Riastini, P.N. (2014). Pengaruh Model Pembelajaran PBL terhadap Keterampilan Proses Sains Siswa Kelas V SD di Gugus IV Diponegoro Kecamatan Mendoyo. Jurnal Mimbar PGSD Universitas Pendidikan Ganesha, 2(1), 1-11.

Pertiwi, D.A. \& Husna. (2013). Peningkatan Sikap IImiah Siswa Melalui Metode Praktikum dengan Pendekatan Inkuiri Pada Materi Termodinamika di Kelas XI IPA SMA Negeri 3 Sanggau. Jurnal Program Studi Pendidikan Kimia FKIP Untan, 3(2), 31-40.

Pramudita, U.G., Probosari, R.M. \& Widoretno, S., (2014). Penerapan 
Problem Based Learning untuk Meningkatkan Kemampuan Berpikir Analitis Siswa Kelas X MIA 6 SMA MTA Surakarta Tahun Pelajaran 2013/2014 pada Materi Pencemaran Lingkungan. Bio-Pedagogi, 3(2), 31-40.

Priadi, M.A., Sudarisman, S., \& Suparmi (2012). Pembelajaran biologi menggunakan model problem based learning melalui metode eksperimen laboratorium dan lapangan ditinjau dari keberagaman kemampuan berpikir analitis dan sikap peduli lingkungan. Jurnal Inkuiri, 1(3). 217-226.

Rahmawanna, R., Adlim, A., \& Halim, A. (2016). Pengaruh Penerapan Pendekatan Chemo-entrepreneurship (Cep) terhadap Sikap Siswa Pada Pelajaran Kimia dan Minat Berwirausaha. Jurnal Pendidikan Sains Indonesia, 4(2), 113-117.

Rezba, R.J., Sprague, C.R., McDonnough, J.T., et.al. (2007). Learning \& Assessing Science Process Skills: Fifth Edition. United State of America: Hunt Publishing Company.

Rofiah ,E., Aminah, N.S., \& Ekawati, E.Y. (2013). Penyusunan Instrumen Tes Kemampuan Berpikir Tingkat Tinggi Fisika pada Siswa SMP. Jurnal Pendidikan Fisika, 1(2), 17-22.

Schmidt, H.G., Rotgans, J.I., \& Yew, E.H.J. (2011). The Process of Problem-Based Learning: What Works and Why. Medical Education 2011 (45), 792-806.

Siwa, I.B., Wuderawan, I.W., \& Tika, I.N. (2013). Pengaruh Pembelajaran Berbasis Proyek dalam Pembelajaran Kimia terhadap Keterampilan Proses Sain ditinjau dari Gaya Kognitif Siswa. E-Journal Program Pascasarjana Universitas Ganesha, 3(2013), 1-13.

Sugiarti \& Bija, S. (2012). Pengaruh Model Pembelajaran Kontekstual terhadap Kemampuan Berpikir Kritis Siswa Kelas
XI A SMA Negeri 3 Watansoppeng. Jurnal Chemical UNM, 2(13), 77-73.

Sujarwo. (2014). Model-Model Pembelajaran Suatu Strategi Mengajar. Yogyakarta: CV. Venus Gold Press.

Sun, R., \& Hui, E. (2012). Cognitive Competence as a Positive Youth Development Construct: A Conceptual Review. The Scientific World Journal, 2012, 1-7.

Supiandi, M.I. \& Julung, H. (2016). Pengaruh Model Problem Based Learning (PBL) terhadap Kemampuan Masalah dan Hasil Belajar Kognitif Siswa Biologi SMA. Jurnal Pendidikan Sains, 4(2), 60-64.

Üce, M., \& Ateş, I. (2016). Problem-based Learning Method: Secondary Education 10th Grade Chemistry Course Mixtures Topic. Journal of Education and Training Studies, 4(12), 30-35.

Utrifani, A. \& Turnip,B.M. (2014). Pengaruh Model Pembelajaran Problem Based Learning terhadap Hasil Belajar Siswa pada Materi Pokok Kinematika Gerak Lurus Kelas X Sma Negeri 14 Medan T.p.2013/2014. Jurnal Inpafi, 2(2), 916.

Wahyudi, A., Marjono, \& Harlita (2015). Pengaruh Problem Based Learning terhadap Keterampilan Proses Sains dan Hasil Belajar Biologi Siswa Kelas $X$ SMA Negeri Jumapolo Tahun Pelajaran 2013/2014. Bio-Pedagogi, 4(1), 5-11. 